\title{
Les Russes - The Image of East European Jews in La Chaux-de-Fonds and Zurich
}

\author{
A Discourse of Power and Fear
}

\section{Introduction}

In this paper I will focus on the perception of East European Jews by the bourgeois Jewish elites in Zurich and La Chaux-de-Fonds. The cities of Zurich in the German-speaking part of Switzerland and La Chaux-de-Fonds in the French-speaking part have been chosen as examples for this survey for two reasons: On the one hand, the local Jewish communities in both cities consisted largely of reform-oriented, fairly wealthy and bourgeois members and can therefore lend themselves to comparison. On the other hand, the number of East European Jews migrating to the two cities differed greatly. While only ten Jewish families settled temporarily in La Chaux-de-Fonds, ${ }^{1}$ the number of Jewish migrants in Zurich was the highest anywhere in Switzerland. From 1876 to 1900, 112 migrants settled with their family members within the city limits, and between 1911 and 1917 another 7,997 East European Jews migrated to Zurich. ${ }^{2}$ From a sociocultural perspective, the cases of La Chaux-de-Fonds and Zurich are highly comparable, as in each case the local bourgeois Jewish community considered itself an integral part of its respective city. From a demographic point of view, the two cities differ considerably: Zurich was home to the largest East European Jewish immigrant community, whereas in La Chaux-de-Fonds the number of East European Jews was extremely small.

1 Archive of the Jewish Community La Chaux-de-Fonds (AjG ChdF). The archival material of the Jewish community is stored unsystematically in two wall cupboards in the local synagogue. However, there are plans for it to be systematized within the coming years and made publicly accessible in the city library. For my research on the history of Jewish watchmakers and entrepreneurs in La Chaux-de-Fonds, I had unrestricted access to the archives and worked through the entire body of material. As there were no call numbers, I categorized the sources myself; all call numbers are therefore my own.

2 All figures for Zurich are taken from: Huser Bugmann, Karin. Schtetl an der Sihl. Einwanderung, Leben und Alltag der Ostjuden in Zürich 1880-1939. Zurich: Chronos, 1998, 81-82. Huser's data is based on: Statistisches Amt der Stadt Zürich: Statistik der Judenwanderung in Zürich 1911-1917 (printed). 
However, despite the difference in number - close to 10,000 East European Jews migrating through or to Zurich compared to just ten families in the case of La Chaux-de-Fonds - the local Jewish communities reacted to these immigrants in a similar - negative - manner. In this paper I will argue that the anti-East European Jewish discourse within the local Jewish bourgeois communities was mostly based on a strong class consciousness within the predominant group.

Between 1880 and 1914 around 3.5 million Jews left Eastern Europe. ${ }^{3}$ Five to seven thousand of them settled in Switzerland, and several tens of thousands more migrated through the country. ${ }^{4}$ The total number of Jews living in Switzerland rose from 7,000 in $1870^{5}$ to 18,000 in $1930 .^{6}$ Taking these numbers into account, even five thousand newly immigrated Jews from the East clearly had an impact on the local Jewish population. Most of the newcomers were poor in their countries of origin and even poorer by the time they reached Switzerland. ${ }^{7}$ However, we must not forget that the group of migrants was highly heterogeneous, as were the reasons for their emigration.

3 Demographic sources for the period before 1900 are not very reliable. The data presented in any survey are best guesses. The YIVO Encyclopedia of Jews in Eastern Europe offers the following figures: Between 1820 and 1870 about 20,000 Galician Jews and about 10,000 Jews from the Russian Empire migrated to the United States. From 1871 to 1880 about 70,000 Jews from Eastern Europe left their homelands for the West. These numbers increased dramatically over the following decades: From 1881 to 1900 some 760,000 Jews left Eastern Europe and from 1901 to 1914 about 1.6 million Jews migrated westwards. In all, prior to World War I about 3.5 million Jews left Eastern Europe. Kupovetsky, Mark. Population and Migration before World War I. In The YIVO Encyclopedia of Jews in Eastern Europe, vol. 2, Gershon Hundert (ed.), 1423-1429. New Haven and London: Yale University Press, 2008, 1427. The majority of the migrants who arrived in Switzerland in the years 1880-1917 came from the Russian Empire; after the First World War the majority came from the newly established Second Republic of Poland. Huser Bugmann, Schtetl an der Sihl, 85.

4 Kury, Patrick. Socio-Cultural Differences, Nationalistic and Anti-Semitic Reflexes: Migration and Jewish Life Worlds in Switzerland in 1900. In Jewish Migration and Integration to the Metropolises of Europe, 1848-1918, Haar, Ingo (ed.). New York: Berghahn Books, 2013 (forthcoming).

5 Statistisches Bureau des eidg. Department des Innern (ed.). Die Bevölkerung nach Geschlecht, Civilstand, Heimath, Aufenthalt, Religion, Gebrechen, Sprachverhältnissen, nebst Zahl der Haushaltungen, der Wohnhäuser und bewohnbaren Räumen. Eidgenössische Volkszählung vom 1. Dezember 1870, vol. 1. Berne: [publisher unknown], 1870, 213.

6 Eidgenössisches Statistisches Amt (ed.). Vorläufige Ergebnisse der eidgenössischen Volkszählung vom 1. Dezember 1930. Berne: [publisher unknown], 1930, 2.

7 See Kury, Patrick. "Man akzeptierte uns nicht, man tolerierte uns!” Ostjudenmigration nach Basel 1890-1930. Basel: Helbing und Lichtenhahn, 1998, 18 and 109-113; Huser Bugmann, Schtetl an der Sihl, 53-64. 
Table 1: Jewish population in Swiss cities in numbers and by percentage of the total population (1870-1920)

\begin{tabular}{|c|c|c|c|c|c|c|c|c|c|c|}
\hline & & 1870 & & 1888 & & 1900 & & 1910 & & 1920 \\
\hline & $\mathrm{n}$ & $\%$ & $n$ & $\%$ & $\mathrm{n}$ & $\%$ & $\mathrm{n}$ & $\%$ & $\mathrm{n}$ & $\%$ \\
\hline Basel $^{8}$ & 504 & 1.14 & 1047 & 1.50 & 1892 & 1.73 & 2451 & 1.85 & 2513 & 1.85 \\
\hline Berne & 303 & 0.85 & 346 & 0.75 & 655 & 1.02 & 1052 & 1.21 & 1039 & 0.98 \\
\hline Biel & 167 & 2.10 & 213 & 1.51 & 336 & 1.53 & 413 & 1.74 & 439 & 1.26 \\
\hline $\begin{array}{l}\text { La Chaux-de- } \\
\text { Fonds }\end{array}$ & 459 & 2.34 & 608 & 2.08 & 914 & 2.54 & 900 & 2.38 & 1005 & 2.67 \\
\hline St. Gallen & 138 & 0.84 & 394 & 1.44 & 419 & 1.27 & 4769 & 2.03 & 1017 & 1.44 \\
\hline Genf 9 & 574 & 1.30 & 541 & 1.04 & 729 & 1.23 & 1186 & 2.03 & 1310 & 2.31 \\
\hline Zurich $^{10}$ & 477 & 0.85 & 1221 & 1.36 & 2713 & 1.80 & 4212 & 2.73 & 6662 & 3.21 \\
\hline
\end{tabular}

Jewish students, male and female, formed one important group among the East European Jewish immigrants. ${ }^{11}$ Between 1870 and 1914, the universities of Zurich, Berne, Geneva, and to some extent Lausanne and Basel allowed young Jews from the Russian Empire and Eastern Europe to enroll. Many of these students were politically active and fears within local bourgeois communities, both Jewish and non-Jewish, were therefore projected onto them as a group. ${ }^{12}$ Students, however, came to Switzerland to study, not to stay. They lived in the country for a few semesters before returning home or migrating to another university city to continue their studies.

8 Urban district (Stadtbezirk) only (without Kleinhüningen until 1900, Bettingen and Riehen).

9 Urban district only.

10 Including the nine outer districts (Ausgemeinden). On January 1, 1893 the city of Zurich was enlarged to include the formerly independent municipalities Aussersihl, Enge, Fluntern, Hirslanden, Hottingen, Oberstrass, Riesbach, Unterstrass, Wiedikon, Wipkingen, and Wollishofen.

11 See the paper by Aline Masé in this volume.

12 Kury, Patrick. Socio-Cultural Differences. 


\section{East European Jews' Encounters with Switzerland and Swiss Jewry}

It was a different story for the ten thousand East European Jews who migrated through Switzerland on their way to their chosen destinations. Until 1912, many emigrants favored the southern route via Genoa to Argentina, but when the fare for this journey more than doubled in price, the northern route via Bremen to the United States became very popular. ${ }^{13}$ Switzerland lay on the southern emigration route and above all St. Gallen on the northeastern and Basel on the northwestern border of Switzerland became important transit places for the migrants. The bourgeois Jewish community in Basel was quick to organize help for them. The Hilfscomité für jüdische Auswanderer, founded in 1906, provided emigrants "with the most reliable information possible about travel routes and opportunities and [represented] their interests to prevent them from being exploited."14 On average, the emigrants stayed two to four days in cities such as Basel and St. Gallen before they continued their travels. ${ }^{15}$ However, not all of these East European Jews left Switzerland - some five to seven thousand remained.

Socioeconomic and cultural differences between Swiss Jews and East European Jewish immigrants led to segregation and exclusion of the latter group. The anti-East European Jewish discourse is deeply rooted in the Swiss Jews' history. At the federal level, Jews in Switzerland were considered foreigners and were denied the basic rights of permanent settlement or professional and religious freedom until 1866. Until then their right of residence was legally restricted to the two villages Endingen and Lengnau near Baden in the north of the country. ${ }^{16}$ Although there have always been exceptions to this restriction, the legal status of Jews in other parts of Switzerland was uncertain, irrespective of how many generations had lived there. Throughout the nineteenth century, Jews from Endingen and Lengnau fought for legal emancipation. ${ }^{17}$

13 Kury, Patrick. Socio-Cultural Differences.

14 Auskunftbureau für jüdische Auswanderer 1905-1911, in: Staatsarchiv des Kantons Basel-Stadt. Quoted in: Kury, Patrick. Socio-Cultural Differences.

15 Kury, Ostjudenmigration nach Basel, 45.

16 See among others: Weldler-Steinberg, Augusta, Florence Guggenheim-Grünberg. Geschichte der Juden in der Schweiz vom 16. Jahrhundert bis nach der Emanzipation. Zurich: Aktiengesellschaft für Verlag und Druckerei, 1966; Guggenheim-Grünberg, Florence. Vom Scheiterhaufen zur Emanzipation. Die Juden in der Schweiz vom 6. bis 19. Jahrhundert. In Juden in der Schweiz. Glaube - Geschichte - Gegenwart, Willi Guggenheim (ed.), 10-53. Küsnacht, Zurich: Edition Kürz, 1982.

17 Guggenheim-Grünberg, Scheiterhaufen, 27-52. 
It was not until 1862 that the Zurich authorities allowed Jews to settle permanently within the canton and city borders. That same year, Jews from Endingen and Lengnau founded the Israelitische Cultusgemeinde Zürich (ICZ), the first Jewish community in Zurich. ${ }^{18}$ They considered their home villages to be the cradle of Swiss Jewry. ${ }^{19}$ Their origin as the "real" Swiss Jews and their fight for emancipation was a crucial part of their Jewish and Swiss identity. Once they were allowed to settle in Zurich, at the time a fast-growing city undergoing rapid economic development, they began a process of successful economic and cultural integration. By the turn of the century, a fair number of these Jews led a comfortable bourgeois life. ${ }^{20}$

Around the same time, Alsatian Jews began migrating to Basel $^{21}$ and to the French-speaking parts of Switzerland, above all the Jura region. ${ }^{22}$ Their part in the fight for legal rights was not comparable to that in Endingen and Lengnau. Migration from the Alsace to the Jura hills began just after the French Revolution, when some Jews came to the region of La Chaux-de-Fonds as cattle dealers. ${ }^{23}$ In 1850, the Jewish community in La Chaux-de-Fonds already numbered 95 persons. ${ }^{24}$ By this time they were trading in watches and watch parts rather than cattle. Watchmaking was the main business in the region, and La Chauxde-Fonds was its uncontested center. ${ }^{25}$ When in 1857 Jews were granted legal

18 Mahrer, Stefanie. Kurze Vorgeschichte der ICZ. In “Nicht irgendein anonymer Verein... ” Eine Geschichte der Israelitischen Cultusgemeinde Zürich, Alfred Bodenheimer (ed.), 15-20. Zurich: Verlag Neue Zürcher Zeitung, 2012; Heinrichs, Ruth. Die Etablierung der jüdischen Gemeinschaft 1862-1890. In Geschichte der Juden im Kanton Zürich. Von den Anfängen bis in die heutige Zeit, Annette Brunschwig, Ruth Heinrichs, Karin Huser Bugmann (eds.), 215-234. Zurich: orell füssli, 2005.

19 This notion was adopted unquestioningly by historians in the twentieth century. Until the 1990s, historians in the field of Jewish history in Switzerland focused on two topics: anti-Semitism and the fight for legal emancipation. The Jews of Endingen and Lengnau played a disproportionately important role in this historiography. It is only in the last two decades that younger historians have begun to explore other topics and thereby shown that Jewish life in Switzerland was much more diverse than had previously been assumed.

20 Heinrichs, Aufbruch in die Moderne, 250-251.

21 See for instance Bennewitz, Susanne. Basler Juden - französische Bürger. Migration und Alltag einer jüdischen Gemeinde im frühen 19. Jahrhundert. Basel: Schwabe Verlag, 2008.

22 Gerber Baumgartner, Chantal. La communauté israélite de Porrentruy aux XIXe et XXe siècles. Geneva: Slatkine, 2010; Mahrer, Stefanie. Handwerk der Moderne. Jüdische Uhrmacher und Uhrenunternehmer im Neuenburger Jura 1800-1914. Cologne: Böhlau Verlag, 2012.

23 Ibid., 67-81.

24 Eidgenössisches Departement des Innern (ed.). Uebersichten der Bevölkerung der Schweiz nach den Ergebnissen der letzten eidgenössischen Volkszählung vom 18. bis 23. März, vol. 1. Berne: [publisher unknown], 1851.

25 Landes, David Saul. Revolution in Time. Clocks and the Making of the Modern World. Cam- 
permission to live in the city, they no longer just traded in watches; they had become leading figures and entrepreneurs in the Swiss watchmaking industry. A major crisis in the sector in the 1870s catapulted the Jewish watchmakers to the forefront of the industry. ${ }^{26}$ As leading manufacturers, they now belonged to the city's elite. ${ }^{27}$ These originally Alsatian Jews never fought politically for their rights; rather, they integrated themselves through their professional lives in their capacity as skillful and outstanding watchmakers and talented businessmen. Their work and achievements for the local industry gained them respect, and by the end of the century they had become an integral part of the leading class. They led a thoroughly bourgeois way of life, be it in their cultural tastes, choice of residential address, or leisure activities. ${ }^{28}$

In the second half of the century, the Jewish populations of Zurich and La Chaux-de-Fonds experienced a dramatic rise in social status. The Jews of Zurich were proud of their heritage and their achievements in the fight for emancipation. By the turn of the century, they considered themselves full members of the bourgeois urban population, ${ }^{29}$ equal to the Christians. This picture was clouded by the awareness that their emancipation dated back less than a generation. Furthermore, they were still subject to anti-Semitic discourse and actions. Nevertheless, Jews in La Chaux-de-Fonds felt a strong affiliation to the watchmaking community into which they had integrated, and as part of this community they were fully-fledged members of the bourgeois elite.

On their arrival in Switzerland, the East European Jewish migrants encountered well-established Jewish communities and were confronted with more or less

bridge, MA, London: Belknap Harvard University Press, 2000, 350-351.

26 See Mahrer, Stefanie. Retter in der Krise. Die Rolle der jüdischen Uhrenpatrons im Überwinden der Uhrenkrise im Jura der 1870er Jahre. In Tachles. Jüdisches Wochenmagazin der Schweiz. Sonderbeilage (2011): 4-5; Donzé, Pierre-Yves. Les patrons horlogers de La Chaux-de-Fonds. Dynamique sociale d'une élite industrielle (1840-1920). Neuchâtel: Editions Alphil, 2007, 88-89.

27 Mahrer, Handwerk der Moderne, 185-229. By the turn of the century, the Jewish population in La Chaux-de-Fonds had risen to 914 persons, 2.54 percent of the total population. Statistisches Bureau des eidg. Department des Innern (ed.). Zahl der Häuser und der Haushaltungen, der Bevölkerung, Unterscheidung der Wohnbevölkerung nach Heimat, Geburtsort, Geschlecht, Konfession und Muttersprache. Die Schweizerbürger nach Heimatkanton und Heimatgemeinde. Eidgenössische Volkszählung vom 1. Dezember 1900, vol. 1. Berne: [publisher unknown], 1901.

28 Mahrer, Handwerk der Moderne, 149-153; Mahrer, Stefanie. Migration und Verbürgerlichung Das Beispiel der jüdischen Uhrmacher in der Schweiz im 19. Jahrhundert. In Zwischenräume der Migration. Über die Entgrenzung von Kulturen und Identitäten, Gertraud Marinelli-König, Alexander Preisinger (eds.), 141-156. Bielefeld: transcript Verlag, 2011, 151-154.

29 On the history of Swiss bourgeoisie, see Tanner, Albert. Arbeitsame Patrioten - wohlanständige Damen. Bürgertum und Bürgerlichkeit in der Schweiz 1830-1914. Zurich: Orell Füssli Verlag, 1995. 
open rejection by them and their members. In many communities the East European Jews remained outsiders for more than one generation; in others they were refused membership. ${ }^{30}$ In addition to the anti-East European Jewish discourse within Swiss Jewry, the migrants were also confronted with open anti-Semitism from the Swiss population at large. Legal and social discrimination were the order of the day. Naturalization was more difficult for East European Jews than for any other group of foreigners. ${ }^{31}$ Swiss authorities were afraid of "foreign infiltration" and advised "particular caution in accepting such applications and block[ing] the path to Switzerland for such unwelcome elements [Polish Jews; S.M.]." ${ }^{32}$ East European Jews were considered foreign, unfit to assimilate, and a danger to the country. ${ }^{33}$ Cantonal laws restricted the freedom of "East European," "Polish," and "Russian" Jews ${ }^{34}$ to work in certain trades such as peddling and added fuel to the discourse of the "unproductive and profiteering Ostjude." 35

The setting in which the East European Jewish immigrants found themselves around 1900 can be summarized as follows: In both Zurich and La Chaux-deFonds there was an economically and culturally integrated Jewish population, most of whose members belonged to the bourgeois class of their respective city. They or their ancestors had fought for civil rights and worked hard for their place in society. With regard to religion, most of them were no longer observant in their daily lives and the congregations tended to be reform-oriented rather than Orthodox. Religion was restricted to the synagogue and was in accordance with bourgeois taste and lifestyle.

30 Kury, Patrick. Socio-Cultural Differences.

31 Huser Bugmann, Schtetl an der Sihl, 95-126.

32 An die Schweizerische Gesandtschaft in Wien, September 19, 1919. Quoted in: Kury, Patrick. Socio-Cultural Differences.

33 See Kury, Patrick. Über Fremde reden. Überfremdungsdiskurs und Ausgrenzung in der Schweiz 1900-1945. Zurich: Chronos, 2003, 132-149.

34 The Swiss authorities failed to clearly define "East European,” "Polish,” and “Russian.” Even in legal matters the use of the adjectives remains vague and is subject to constant variation.

35 The labeling of (East European) Jews as "unproductive and profiteering" is a common anti-Semitic stereotype. See Kury, Ostjudenmigration nach Basel, 57-58. 


\section{Motives in the Anti-East European Jewish Discourse}

Rejection by Swiss Jews, legal restrictions, and anti-Semitism ${ }^{36}$ all made life difficult for the East European Jews. The focus of this paper, however, is not the actual life of the transitory migrants and immigrants, ${ }^{37}$ but how the Swiss Jews perceived them. Two main sets of discourses will be highlighted: (1) East European Jews as objects of philanthropy in La Chaux-de-Fonds, and (2) the negative connotation of "typical” East European Jewish professions in Zurich. Although these are two completely different discourses, I will argue in the second part of this paper that they have one thing in common: Both the reducing of Eastern European Jews to objects of philanthropy and the labeling of the immigrants as representatives of disreputable professions stem from feelings of fear and of power.

I focus mainly on the year 1905 due to the fact that it marks the first peak of Russian Jewish immigration to Zurich. ${ }^{38}$ The outbreak of the Russo-Japanese War (1904-1905) and the Russian Revolution of 1905 triggered a wave of pogroms. The Tsar deliberately supported these anti-Semitic riots with measures including having The Protocols of the Elders of Zion read in all Moscow churches. ${ }^{39}$ In the course of these events, tens of thousands of Jews fled westwards. Zurich was heavily affected by the flow of refugees. By mid-1906, 219 "tolerated" 40 Russian Jews lived in the city. When another 120 paperless immigrants arrived from Tsarist Russia, the authorities decided not to tolerate these "disagreeable people" any longer. ${ }^{41}$ The Jewish communities in Switzerland were confronted with the needs of the refugees from a different social and cultural background - a circumstance that resulted in misunderstandings, difficulties, and ultimately rejection.

Source material on the question of how the East European Jews were perceived by the Swiss Jews is sparse, for La Chaux-de-Fonds even more so than for Zurich. For La Chaux-de-Fonds, the documents of the local Jewish philanthropic

36 East European Jews were victims of a distinctive form of anti-Semitism. See Ibid., 132-139.

37 These matters have been addressed by other historians. Patrick Kury has studied the situation in Basel, Karin Huser Bugmann that in Zurich. Huser Bugmann, Schtetl an der Sihl; Kury, Ostjudenmigration nach Basel.

38 The largest immigration of East European Jews took place between 1905 and 1914. See Huser Bugmann, Schtetl an der Sihl, 81.

39 The Protocols of the Elders of Zion were first published in 1905 by Sergei Nilus, a Russian occultist. Hagemeister, Michael. Der Mythos der "Protokolle der Weisen von Zion". In Verschwörungstheorien: Anthropologische Konstanten - historische Varianten, Ute Caumanns, Mathias Niendorf (eds.), 89-101. Osnabrück: fibre, 2001, 95.

40 "Tolerated" was the official term for foreigners with (temporary) resident permits.

41 Huser Bugmann, Schtetl an der Sihl, 91-93. 
society are the main, and almost the only, sources. ${ }^{42}$ The migrants were without means and dependent on Jewish welfare. Members of the philanthropic societies recorded whatever they considered important in this context. As far as is known at this point in time, there are no extant sources originating with the East European Jewish immigrants themselves.

The weekly newspaper Israelitisches Wochenblatt für die Schweiz (IW) proved a rich source of information on how East European Jews were perceived by Jews from Zurich. ${ }^{43}$ David Strauss and Rabbi Martin Littman founded the IW in $1901 .{ }^{44}$ The two men, both members of the ICZ, were the paper's publishers until 1918 and left a strong imprint on its content and political orientation. In its first years of publication, the paper consisted of about ten pages and published news from the Jewish world in Switzerland and abroad as well as announcements of births and deaths. By 1930 it was a 40-page weekly with a German- speaking readership that reached far beyond Switzerland's borders. ${ }^{45}$ Despite its more international orientation, the IW still functioned as the main forum for information concerning Swiss Jewish life with a strong focus on Zurich.

As the present paper concentrates on a detailed description of perceptions of the East European Jewish immigrants, I have worked exclusively with the aforementioned sources. ${ }^{46}$ Information beyond the scope of this specific field of enquiry draws on secondary literature.

\section{"Ostjuden" in La Chaux-de-Fonds - The East European Jewish Immigrants as Objects of Philanthropy}

Philanthropy has a strong tradition within Judaism. Helping the poor is more than just a good deed - it is a religious obligation..$^{47}$ Hevrot, the traditional ben-

42 Caisse centrale de la Bienfaisante de la Chaux-de-Fonds (notebook), 1900-1910. AjG ChdF.

43 The author thanks Tamar Lewinsky for sharing her insights on this topic.

44 Litmann served as rabbi, Strauss as religious education teacher at the ICZ. The ICZ was the largest Jewish community in Zurich. It was founded in 1862 by Jews from Endingen and Lengnau. On the history of the community, see Bodenheimer, Alfred (ed.). "Nicht irgendein anonymer Verein ... ” Eine Geschichte der Israelitischen Cultusgemeinde Zürich. Zurich: Verlag Neue Zürcher Zeitung, 2012.

45 Marx, Erich. Zum 30. Jahrestag, IW, January 3, 1930, 3.

46 On related sources for Zurich, see Huser Bugmann, Schtetl an der Sihl, 16-19.

47 See for instance: Lässig, Simone. Jüdische Wege ins Bürgertum. Kulturelles Kapital und sozialer Aufstieg im 19. Jahrhundert. Göttingen: Vandenhoeck \& Ruprecht, 2004, 319. 
eficial societies, played an important role in community organization. ${ }^{48}$ They took care of the sick and the poor, organized funerals, and so on. In La Chaux-deFonds, there were three philanthropic societies - two for men and one for women. For most women of the bourgeois class, philanthropic work was the only field of activity in which they engaged outside of the home. ${ }^{49}$

La société des dames was one of the oldest institutions of the Jewish community of La Chaux-de-Fonds. Founded in 1854, the organization primarily cared for orphans, the sick, and the elderly. In 1863, young bachelors founded La Bienfaisante with the main purpose of supporting unmarried men and apprentices, but also to organize social gatherings. The third philanthropic society, La société philanthropique, was founded in 1867 by married men. The chief purpose of this last society was to support married men and their families in case of need. Before the beginning of the twentieth century, public welfare was not yet established and private charity played an important role. The three Jewish philanthropic societies protected all members of the Jewish community in case of need, and they also played an important role in the wider Jewish world. They provided direct financial support to Jewish families in the Alsace as well as in Palestine; furthermore, international societies like the Alliance Israélite Universelle could count on regular financial contributions from the three societies. ${ }^{50}$

When the East European Jews reached La Chaux-de-Fonds, they received support from La Bienfaisante and La société des dames. Almost all of our information about these families is from the records of these two societies.

We find the first mention of an East European Jewish family in La Chaux-deFonds in January 1906. By May 1906, there were six families, and this number had risen to ten by the beginning of $1907 .{ }^{51}$ As a growing industrial city, La Chauxde-Fonds attracted thousands of migrants from other Swiss cantons as well as from Italy and France. Indeed, the success of the watchmaking industry would not have been possible without the immigrant labor force. ${ }^{52}$ However, it seems that Jews from the East were not attracted to this city, despite its constant need for workers and its reputation as the home of a relatively affluent Jewish commu-

48 Ibid., 520-523.

49 See Mahrer, Handwerk der Moderne, 213-216.

50 Caisse centrale de la Bienfaisante de la Chaux-de-Fonds (notebook), 1900-1910. AjG ChdF; Several cash ledgers of the Bienfaisante, 1868-1910. AjG ChdF; Correspondence of the Bienfaisante, 1864-1914. AjG ChdF.

51 Caisse centrale de la Bienfaisante de la Chaux-de-Fonds (notebook), 1900-1910. AjG ChdF.

52 For a general history of watchmaking in La Chaux-de-Fonds, see Donzé, Pierre-Yves. Histoire de l'industrie horlogère suisse. De Jacques David à Nicolas Hayek (1850-2000). Neuchâtel: Editions Alphil, 2009. For a history of the city: Cop, Raoul. Histoire de La Chaux-de-Fonds. Le Locle: Editions d'Encre, 2006. 
nity. We can only speculate about the reasons for the very limited number of East European Jews in La Chaux-de-Fonds. La Chaux-de-Fonds lies geographically at the periphery of the country, far away from any traditional migration routes. For those planning to migrate further westwards, La Chaux-de-Fonds would have been a detour, and for students the city was not even on the map since there was no university. For these or other unknown reasons, the number of East European Jewish immigrants in La Chaux-de-Fonds remained very small, even during the peak migration period from 1905 to 1914. In comparison with Zurich, and also with Basel, the Jewish community of La Chaux-de-Fonds was not confronted with large numbers of poor migrants requiring assistance. Nevertheless, despite the very small number of East European Jewish immigrants, the philanthropic societies of La Chaux-de-Fonds were not very generous in their support.

The weekly assistance provided to East European Jews was primarily paid in kind. They could expect no more than bread and milk, in contrast to local Jewish families in need, meaning those either born in La Chaux-de-Fonds or having immigrated from the Alsace, who received higher amounts and were paid in cash. However, in cases when Jews from the East planned to leave La Chaux-de-Fonds and Switzerland for good, each family member received 200 Swiss francs and a third class one-way ticket to another European city. 200 Swiss francs was a considerable sum ${ }^{53}$ if one considers that the average monthly expenses for all of the ten families together amounted to 250 Swiss francs. ${ }^{54}$

The Jewish community did not force their East European brethren to leave the city, but it clearly discouraged them from staying. As long as East European Jews were living in La Chaux-de-Fonds, the main goal of the Société des dames was to educate them in hygiene and cleanliness. The women consistently complained about the shabbiness of East European Jews' homes, about their lack of personal hygiene and their poor health. ${ }^{55}$ It is difficult to tell whether the living conditions of families from Eastern Europe were actually as bad as described in the files, or whether the Swiss Jews adopted a general stereotype in order to distance themselves from the immigrants. If one looks at the places of residence within the city, East European Jews lived amidst the local Jews and gentiles in the center of the town, not in the poor neighborhoods in the east of the city, where the Christian working classes had their homes. ${ }^{56}$

53 As a comparison, a bottle of Fendant (white wine) in a local restaurant cost 2 francs. In: Restaurant bill, January 25, 1912. IB Jüd Gemeinde St Imier / 20, Archiv für Zeitgeschichte der Universität Zürich (AfZ).

54 Caisse centrale de la Bienfaisante de la Chaux-de-Fonds (notebook), 1900-1910. AjG ChdF.

55 Ibid.

56 Mahrer, Handwerk der Moderne, 212. 
What becomes quite clear from the discourse about "Ostjuden" in the philanthropic circles of the local Jewish bourgeoisie is that philanthropy served as a means of distinction. The repeated reference to the "otherness" of the East European Jews set them apart from the established community. All of the terms used by the philanthropic societies to describe East European Jews carry explicitly negative connotations. They served both to degrade the immigrants and to consolidate the status of the Swiss Jews.

\section{Beggars and Peddlers - The Image of East European Jews in Zurich's Jewish Press}

Fifty percent of all East European Jews who migrated to Switzerland between 1880 and 1965 worked in commerce; almost twenty percent were academics, and eighteen percent craftsmen and businessmen. ${ }^{57}$ Since most of them were self-employed, it is difficult to determine how many of the merchants actually worked as peddlers.

Peddlers generally had a very bad reputation. Most of them were extremely poor and tried to make a living out of nothing. Between 1900 and 1905, 4.6 to 7.3 percent of all peddlers in Zurich were of East European Jewish origin. Although this is not a particularly high percentage, the presence of the peddlers shaped the general image of East European Jews within Jewish and non-Jewish society. In 1905 the canton of Zurich enacted a ban on Russian peddlers. Most of those affected by the prohibition were Russian Jews. ${ }^{58}$

The Jewish communities had their own problems with beggars and peddlers. First of all, most families of peddlers depended on outside financial support. Jews who had only entered the country in order to continue further west, in particular, lived on begging, occasional peddling and charitable donations. In September 1906, the Jewish community in Basel established a contact point for East European Jewish immigrants. The Jewish community fed them, organized accommodation and paid train fares to the next destination. ${ }^{59}$ It took much longer for a comparable institution for East European Jews to be organized in Zurich, and it was only in 1920 that the Jüdisches Emigrations Comité was founded. Until then, the body in charge of relief for the poor (Armenpflege) and the welfare committee (Fürsorgekommission), both ICZ institutions founded in 1914, took care of the

57 Ibid., 137.

58 Ibid., 140.

59 Kury, Ostjudenmigration nach Basel, 42. 
stranded immigrants. The means of the two institutions, however, were insufficient to meet the needs of all of the immigrants, and many were forced to beg for money elsewhere. ${ }^{60}$

My analysis of the IW reveals that Swiss Jews made little distinction between peddlers and beggars. ${ }^{61}$ The IW even observed a lack of differentiation between immigrants who came and were allowed to stay in the country and those who were only passing through.

Although the IW sought to be objective in its coverage of East European Jews, it was still the voice of the established Jewish community of Zurich, the community that had to finance the immigrants. A leading article from January $1905^{62}$ - the year of the revolution that pushed thousands of Jews into emigration - provides a good illustration of general opinion on the Jewish refugees. The article begins with a reference to the increasing immigration of Russian Jews. The author suggests three principles in dealing with this "acute problem:"63

Firstly [...] nothing must be done that could increase the immigration of illiterates to Zurich, a location that is already privileged in this respect. Especially under current conditions, any easing of restrictions on obtaining the right to residence ${ }^{64}$ would soon become known to all concerned, and would be a new reason for Zurich to receive preference as an immigration destination. [...] Secondly, payment of the deposit [Kautionsleistung] should be denied to all who are unworthy of it. [...] Thirdly, the matter should be solved as far as possible by means of self-help rather than charity.

Erstens [...] darf nichts getan werden, was die Einwanderung Schriftenloser auf den in dieser Hinsicht sowieso schon privilegierten Platz Zürich noch vermehren könnte. Eine Erleichterung der Möglichkeit die Toleranzbewilligung zu erlangen wäre besonders bei den heutigen Verhältnissen unter den Beteiligten sicher bald genug bekannt und wäre ein neues Motiv Zürich als Einwanderungsort zu bevorzugen [sic]. [...] Zweitens sollte die Kautionsleistung für alle diejenigen abgelehnt werden, die derselben unwürdig sind. [...] Drittens sollte unsere Frage möglichst nicht auf dem Wege der Wohltätigkeit, sondern auf dem der Selbsthilfe gelöst werden [...]. ${ }^{65}$

60 Die jüdischen Durchwanderer in Zürich, IW, November 26, 1920, 1-2.

61 The IW published an article on the subject of peddlers and beggars: Brandenburger, Otto. Die Hilfe für den jüdischen Durchwanderer, IW, April 27, 1923, 2.

62 Dr. Mamelot. Zur Frage der Toleranzbewilligung, IW, January 25, 1905, 1.

63 Ibid.

64 In Zurich, foreigners without a valid passport had to pay a security guarantee in the amount of 1,500 Swiss Francs for an individual and 3,000 Swiss Francs for a family. Hardly anyone was capable of paying such an amount. The other option was what was known as the Personalkaution: Two persons, both of whom resided in Zurich and regularly paid taxes, could act as guarantors for the money. See Huser Bugmann, Schtetl an der Sihl, 95.

65 Mamelot, Zur Frage der Toleranzbewilligung, 1. 
This passage makes the general tendency quite clear: The stated goal was to make Zurich as unattractive as possible to the immigrants. Help should not be granted to the unworthy. The problem, however, is that the leading figures in philanthropic societies - in all likelihood representatives of the Jewish bourgeoisie defined who was worthy and who was not. The author of the article, Dr. Mamelot, a lawyer from Zurich, names the undeserving refugees: In addition to common criminals, it was the deserters who were a thorn in his side. Someone who does not carry out his duty for his fatherland does not, in his view, deserve any help.

In these cases, philanthropy became an instrument of power. Those providing the money had the power to define who would be helped and who was not worthy of support. By excluding specific groups from receiving assistance, they also sought to consolidate their own identity.

\section{Les Russes - a Discourse of Power and Fear. Thoughts on the Exclusion of an Immigrant Group}

This final section examines some of the aforementioned images of the "other" in an attempt to explain why the Jews of Zurich and La-Chaux-de-Fonds were so explicit in their creation of a clear distinction between themselves and the Jewish immigrants from Eastern Europe. Mamelot offers a first example for this strategy of "othering" the immigrant:

But I already hear the usual objection: Is it not mostly a question of Russia, and is Russia not a fatherland for the Jew, towards which he has certain obligations? In any case, this is what I believe, and we West European Jews, of all people, should avoid declaring the opposite after all, we state so often with empathy that we want to fulfill our duties of citizenship at any cost, without regard to how we are treated. What is to be made of the honesty of this avowal if we suddenly make an about-face with respect to the Russian Jews?

Ich höre aber schon den gewöhnlichen Einwand: Handelt es sich in den meisten Fällen nicht um Russland, und ist Russland für den Juden ein Vaterland, gegen das er Pflichten hat? Allerdings glaube ich das, und gerade wir westeuropäischen Juden sollten uns hüten das Gegenteil zu behaupten, betonen wir doch so oft mit Empathie, dass wir unsere Staatsbürgerpflichten um jeden Preis erfüllen wollen, ohne Rücksicht darauf, wie man uns behandelt. Was ist von der Ehrlichkeit dieser Behauptung zu halten, wenn wir plötzlich bezüglich der russischen Juden ganze Wendung machen ${ }^{66}$

66 Ibid. 
Hosting and helping Russian Jewish deserters put the credibility of the Swiss Jews' loyalty to the state of Switzerland at risk. This risk was averted by an open and clear rejection of these refugees. Some thirty years after the successful legal emancipation of the Jews in Switzerland, the fear of being accused of double loyalty remained. A member of the ICZ described this fear as a "ghost" - the ghost of double loyalty that wandered around, frightening Swiss Jews. ${ }^{67}$ In 1905, Swiss Jews received regular visits from this ghost.

Throughout Europe Jews continued to oppose the notion that they belonged to a different people and were therefore unfit to serve a non-Jewish ruler or state. The doors to emancipation only opened when Jews succeeded in convincing the decision-makers that Judaism was nothing more than a religion or denomination. Nevertheless, accusations of a uniquely Jewish double loyalty remained widespread. In this context the absolute rejection of Russian Jewish deserters becomes explicable.

Zionism triggered similar reactions within Swiss Jewry. A fair number of the East European Jews were at least positively disposed towards Zionist ideas. Among the East European Jewish student body in particular, Zionism played an important role. Many students were active in local Zionist groups, and there were Zionist-oriented student unions. ${ }^{68}$ By contrast, Zionism was hardly ever discussed among the Jewish bourgeoisie of La Chaux-de-Fonds. The subject was raised only in the aftermath of the First Zionist Congress in Basel in 1897. In his sermon for Rosh Hashana in 1897, Rabbi Jules Wolff of the Jewish community of La Chaux-de-Fonds recalled some of the many discussions he had had on the subject with community members. They believed that Zionism had developed within East European Jewry as a reaction to constant rejection, persecution, and anti-Semitism. West European Jews, on the other hand, lived in civilized countries and enjoyed the same rights as the Christian population. "Western Jews" therefore had absolutely no reason to long for another homeland. Rabbi Wolff felt sympathy for the suffering of the East European Jews, he said, but he was compelled to reject the ideas of Zionism. Jews, according to Wolff, had not been a nation for eighteen centuries and had no political ambitions whatsoever. In his view, utopian dreaming of this kind had no place in Judaism because the Jews of Western Europe already had a home of their own, a home that protected them and to which they were loyal. ${ }^{69}$

Reactions to Zionism within the ICZ included views comparable to those expressed by the Rabbi in La Chaux-de-Fonds, but whereas in La Chaux-de-Fonds

67 GV, July 6, 1953. IB SIG-Archiv - 2.6.3.26 Israelitische Cultusgemeinde Zürich ICZ, AfZ, 8.

68 Huser Bugmann, Schtetl an der Sihl, 160-166.

69 Wolff, Jules. Sermon pour le Nouvel-An, September 1897. AjG ChdF. 
no known member of the Jewish community openly supported the Zionist movement, there were active Zionists in Zurich and within the ICZ itself. In the person of David Farbstein, a leading political Zionist of his time, a member of the ICZ, and an East European Jew himself, the community was directly confronted with this political movement. The bourgeois community made it clear that Zionism as an international movement contradicted the ICZ's policy of full assimilation and Swiss patriotism. ${ }^{70}$

Generally speaking, Zionism did not have many supporters among Swiss Jewry. The idea of a Jewish nation state was inconsistent with the strong feeling of being a part of the state of Switzerland..$^{71}$ Swiss Jews, like other emancipated Jewish communities in other Western European countries, felt no need to look for a new homeland. East European Jews, who lived in unprivileged conditions, without legal rights and equality, were set apart from this group. Only the poor and the persecuted, it was implied, needed to dream and speculate about a place where they would be safe.

The rejection by Swiss Jews of the Zionists and of the Russian Jews who had deserted from the Tsarist army indicated a latent fear of being accused of double loyalty. Disassociating themselves from Russian Jews was not only a means of self-identification as a bourgeois group but also a strong sign to the outside, Christian world. The continuous protestations of loyalty stemmed from the latent fear that they were not quite equal, that they were still "the other." By "othering” the Russian Jews, the Swiss Jews made themselves a little more Swiss.

Distance between Swiss Jews and East European Jews was not only constructed politically, but also socially and culturally. In matters of professional life, peddlers were particularly exposed in a negative way, as the following quotation clearly illustrates.

The complaint has often been made that we have too many Jewish peddlers from Russia and Galicia here who attract unwelcome attention through their occupation and customs. The reference is to Jewish craftsmen and workers from Russia, who could not be a burden on anyone, who want to earn their bread honestly and through hard work, and who certainly do not dishonor Swiss Judaism. Who will help us to create a Jewish work certificate within modest boundaries for these people? The relief for the poor would gladly include this in its activities.

70 Zweig-Strauss, Hanna. David Farbstein (1868-1953). Jüdischer Sozialist - sozialistischer Jude. Zurich: Chronos Verlag, 2002, 54-57.

71 Guth Biasini, Nadia. Basel und der Zionistenkongress. In Der Erste Zionistenkongress von 1897. Ursachen, Bedeutung, Aktualität. “... in Basel habe ich den Judenstaat gegründet,” 131-140. Basel: Karger, 1997, 140. 
Es ist oft darüber Klage geführt worden, dass wir zu viel [sic] jüdische Hausierer aus Russland und Galizien hier haben, die durch ihr Gewerbe und durch ihre Sitten unangenehm auffallen. Hier handelt es sich jetzt um jüdische Handwerker und Arbeiter aus Russland, die keinem lästig sein könne, die ehrlich und fleissig ihr Brot verdienen wollen und dem schweizerischen Judentum gewiss nie zur Unehre gereichen. Wer hilft uns in bescheidenem Rahmen für diese Leute einen jüdischen Arbeitsnachweis zu schaffen? Die Armenpflege wird auch das gerne in den Bereich ihrer Tätigkeit nehmen. ${ }^{72}$

"Good immigrants" such as craftsmen and workers, who did not attract negative attention by peddling or begging, were supported. Again we see an expression of the fear that immigrants could cast a damning light on Swiss Jews. In 1905, Jewish poor relief organizations in Zurich refrained from supporting peddlers altogether:

In its support work, too, the relief effort for the poor has had to institute cuts. It no longer supports anyone who wants to settle here without a definite occupation and without any means of their own, because experience shows that the profession of peddler - not well regarded in any case - is already overcrowded, that newly immigrated peddlers find no place to make an honest living, and it would be a sin to support anything other than an honest living.

Auch für ihr Unterstützungswerk hat die Armenpflege bereits in mancher Beziehung Einschränkungsmassregeln treffen müssen, sie unterstützt niemand [sic] mehr, der ohne bestimmtes Gewerbe und völlig mittellos sich hier niederlassen will, weil die Erfahrung zeigt, dass der ohnehin nicht gern gesehene Hausiererwerb bereits überhäuft ist, dass der neueinwandernde Hausierer keinen Raum mehr für ein ehrliches Schaffen findet, und anderes zu unterstützen wäre Sünde. ${ }^{73}$

In 1905, when the immigration of East European Jews began to increase, the Jewish community of Zurich was quick to differentiate between "good" and "bad" immigrants. The good ones, craftsmen and workers, could expect financial support and help settling in. Peddlers, who were often equated with Schnorrer (beggars), were considered dishonest and could therefore not expect any help.

The Swiss were annoyed by the manners and what they saw as the laziness of the peddlers. Swiss Jews were very concerned that the allegedly negative behavior of Russian peddlers would reflect on them. Having attained a certain social standing, they feared losing what they had achieved thus far.

Despite the highly critical tone adopted towards East European Jews in the Jewish press, the IW kept a close eye on general media coverage concerning Jews and Jewish subjects and did not tolerate open criticism from the outside world.

72 Littmann, Martin. Arbeitsnachweis, IW, February 17, 1905, 1.

73 Ibid. 
In an article entitled "Swiss journalism and the Jews,"74 the author expressed his disapproval of attacks on Jews in Switzerland. He noticed a growing anti-Jewish tendency in the press.

Recently, the immigration of Russian Jews who, due to the tragic circumstances in their unfortunate home country, come to the free country of Switzerland, has met with a rather cool reception in the press. Here, as usual, the number of immigrants is exaggerated and the specter of inundation by the Russians is invoked. The situation cannot be so dire! The few hundred Jews certainly do not burden Switzerland; rather, they place obligations on their coreligionists [...]. [...] Many of the immigrants who have not learned a proper trade become peddlers. As long as only a few practiced this profession, the authorities turned a blind eye to the situation and granted permits. Now that more want permits to be peddlers, individual cantons are barring the gates and turning the petitioners away for reasons that are well known. [...] Whoever earns his bread honestly, even by peddling, has the right to travel in the country. [...] The Jews in Switzerland are good citizens; they try to bring honor to their names and to have good relations with the inhabitants. The increase in industrious, active, and sober Jews can only be useful to Switzerland, and their number is so small that they are submerged in the crowd of other inhabitants.

In neuerer Zeit findet die Zuwanderung russischer Juden, die wegen der traurigen Zustände in ihrem unglücklichen Heimatlande nach der freien Schweiz kommen, eine gewisse kühle Aufnahme in den Journalen. Es wird hier wie gewöhnlich die Anzahl derselben übertrieben und bereits das Schreckgespenst der Überflutung durch die Russen an die Wand gemalt. So gefährlich kann die Sache nicht sein! Die wenigen hundert Juden fallen gewiss der Schweiz nicht zur Last, schon mehr verpflichten sie ihre Glaubensgenossen [...]. [...] Viele der Einwandernden, die keinen rechten Beruf erlernt haben, werden Hausierer. Solange es nur wenige waren, die diesen Beruf ausübten, drückten die Regierungen das Auge zu und gaben Patente aus. Jetzt, wo es schon mehr sind, die Hausierpatente verlangen, schieben die einzelnen Kantone die Riegel vor und weisen aus den bekannten Gründen die Gesuchsteller ab. [...] Wer ehrlich und redlich sich im Land sein Brot verdient, ist auch als Hausierer im Rechte sich im Lande zu bewegen. [...] Die Juden in der Schweiz sind gute Bürger des Landes, suchen ihrem Namen alle Ehre zu machen und wünschen mit den Einwohnern auf gutem Fusse zu stehen. Der Zuwachs von fleissigen, tätigen und nüchternen Juden kann der Schweiz nur von Nutzen sein und die Anzahl derselben ist so gering, dass sie in der Menge der übrigen Einwohner verschwinden.

In 1905, the Swiss Federal Council decided to cease granting peddlers' permits. Despite their own reservations, leading Jewish figures in Zurich disapproved of these measures. ${ }^{75}$ The situation initially appears rather paradoxical: Jewish charity decided not to support Russian Jewish peddlers under any circumstances and declared them undesirable, but then condemned the same decision by the

74 Die schweizerische Journalistik und die Juden, $I W$, June 23, 1905, 1.

75 Littmann, Martin. Das Hausierverbot im Kanton Zürich, IW, September 15, 1905, 1; Die Hausiererfrage, $I W$, October 4, 1905, 2-4. 
Swiss authorities. The refusal to grant Russian Jews the authorization of a peddling license was understood as an attack on all Jews in Switzerland. Swiss Jews are good citizens, and therefore, according to the author of the article, any measures against Jews cast doubt on this fact. On closer scrutiny, the situation is not as paradoxical as may at first appear. Jewish welfare organizations were cautious about whom they supported in order to avoid criticism or attacks from cantonal or federal authorities, or, even worse, from non-Jewish public opinion. To forestall expressions of anti-Jewish sentiment or anti-Jewish agitation, they emphasized the loyalty and achievements of the Swiss Jews.

The exclusion of East European Jews not only served the Swiss Jews as a means to distance themselves from the negative discourse the former could arouse in the non-Jewish sphere, but also as a cultural and social boundary. Jews in both Zurich and La Chaux-de-Fonds largely integrated into the bourgeois class. As established merchants, entrepreneurs, academics, physicians and lawyers, they belonged to the local bourgeoisie. This class, although it was highly heterogeneous, was in possession of a certain amount of wealth and shared a common set of tastes and values and a common cultural and educational background. ${ }^{76}$ The poor and culturally different East European Jews did not fit into this group. The only commonality was their Jewishness. But even being Jewish meant something different to the Jews of the ICZ and the Jewish community of La Chaux-deFonds than it did to those from Poland, Galicia, and Russia.

Jules Wolff of the La Chaux-de-Fonds rabbinate praised the Russian Jews for their regular attendance of the synagogue. In contrast to the assimilated La Chaux-de-Fonds Jews, Rabbi Wolff wrote, they at least practiced Judaism in their everyday lives. He also noted their different, much more traditional understanding of Judaism. ${ }^{77}$ Despite the differences concerning the observance of halakhic law - the synagogue of La Chaux-de-Fonds had an organ and a mixed choir - the East European Jews did not establish their own synagogue. ${ }^{78}$ It can only be surmised that the number of East European Jews was too small to form a congregation of their own.

In Zurich, matters were different. As early as 1895, the Orthodox members of the ICZ left the community to found their own, more traditional congregation. The Israelitsche Religionsgesellschaft (IRG) was a characteristic Austrittsgemeinde (secession community) in the tradition of the Israelitische Religionsgesellschaft in Frankfurt a. M. Many East European Jews initially joined the IRG because it was

76 Schäfer, Michael. Geschichte des Bürgertums. Eine Einführung. Stuttgart, Cologne: Böhlau, 2009, 39-40.

77 Wolff, Jules. L'instruction religieuse, La Chaux-de-Fonds, 1907, 5. AjG ChdF.

78 Mahrer, Handwerk der Moderne, 225. 
more in accordance with their understanding of Judaism than the aesthetics and the liberal services at the ICZ synagogue. ${ }^{79}$ However, while the IRG might have followed the minhag ashkenas, a strict rite according to the Frankfurt example, it was just not the kind of tradition that East European Jews were used to. In 1912 the East European Jews created their own shtibl and in 1924 they founded Agudas Achim, their own community with a synagogue of its own. ${ }^{80}$

Unlike in La Chaux-de-Fonds, the East European Jews of Zurich lived in a separate neighborhood where they soon established a Jewish infrastructure: places for prayer, kosher shops and butchers. ${ }^{81}$ These establishments made it possible to lead a Jewish life according to the halakhic law and the specific East European Jewish traditions.

The cultural and religious differences between "Ostjuden" and "Westjuden" were not a very frequent topic in the IW, despite repeated references to the different morals and manners of East European Jews in the context of the peddling question. However, there were clear distinctions between the groups, as reflected in the power structure of the ICZ. All ICZ office-holders were Swiss Jews. ${ }^{82}$ Moreover, throughout the twentieth century, almost all ICZ presidents were related by birth or marriage. ${ }^{83}$

East European Jews were excluded not only from positions of power but also from social clubs. When the Augustin Keller Loge, the Zurich lodge of the B'nai B'rith, was founded in 1907, only wealthy men of the bourgeois elite were granted membership. Conditions of admission included material prosperity and a willingness to become involved in philanthropic work. The foundation of the lodge and its inscrutable policy of inviting potential members evoked angry reactions. ${ }^{84}$ The lawyer and social democratic politician David Farbstein attacked the Augustin Keller Loge as an undemocratic center of power on the fringes of the ICZ. ${ }^{85}$

Power and authority within Jewish Zurich lay with the bourgeois elite. East European Jews, especially those of the first generation, hardly ever succeeded in gaining admittance to these social circles.

79 Huser Bugmann, Schtetl an der Sihl, 79.

80 Ibid., 80.

81 Ibid., 130.

82 Gerson, Daniel. 1862-1914: Bürgerliches Selbstbewusstsein, Etablierung, Akkulturation, erste Spaltungen und Anfeindungen. In “Nicht irgendein anonymer Verein...” Eine Geschichte der Israelitischen Cultusgemeinde Zürich, Alfred Bodenheimer (ed.), 21-80. Zurich: Verlag Neue Zürcher Zeitung, 2012, 73.

83 Ibid., 72.

84 Ibid., 76.

85 Gerson, Bürgerliches Selbstbewusstsein, 76. 


\section{Conclusion}

The exclusion of East European Jews can be understood as an act of power. Exclusion happened on different levels and served different goals. For the established Jews of Zurich and of La Chaux-de-Fonds (and the same is true of other Swiss cities, too) it served as a means of strengthening their own self-image. The discourse on the foreign appearance and lack of hygiene of East European Jews depicted them as inferior and less cultivated. One can clearly speak here of a class discourse. The acculturated, integrated urban Jewish bourgeoisie had nothing in common with the poor, traditional, and sometimes even politically active Jews from the East. Since the bourgeoisie was the leading group in the Jewish communities, its representatives were involved in the community's organizations, such as the philanthropic societies. Press organs such as the IW were likewise in the hands of ICZ members. The Russian peddlers, as we have seen, were considered undesirable and therefore deprived of all chance of receiving financial support.

The case of the Russian peddlers makes it clear that certain reactions were motivated by political considerations. Swiss Jews had to fight for a long time to gain equal rights and even longer to prove that they were as Swiss as the Christian citizens, that they followed respectable trades, that they were loyal citizens. Latent and legitimate fears that they could be put on the same level as East European Jews led them to exclude the recent immigrants.

A consolidated view of all these factors indicates that both clearly class-related exclusion and the fear that the newly immigrated Jews from the East could jeopardize the social position of Swiss Jewry had a strong impact on the anti-East European Jewish discourse within the bourgeois Jewish communities of these years. 


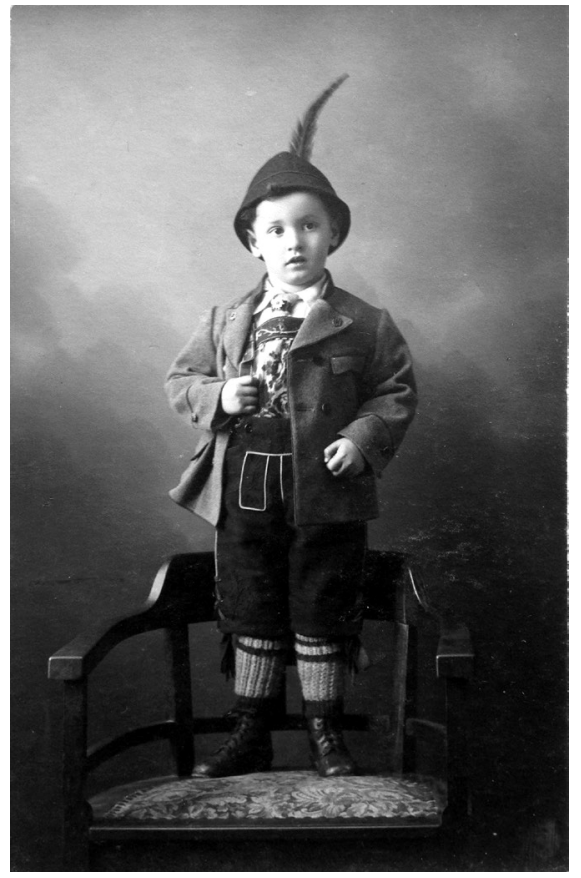

Figure 1: Erwin Halpern, b. 1917 in Zurich. His mother, who immigrated with her family from Gombin in Tsarist Russia when she was still a child, lost her Swiss citizenship when she married Erwin's father, a tailor from the Galician town of Zarszyn. After his mother's premature death in 1918, the boy was raised by his maternal family.

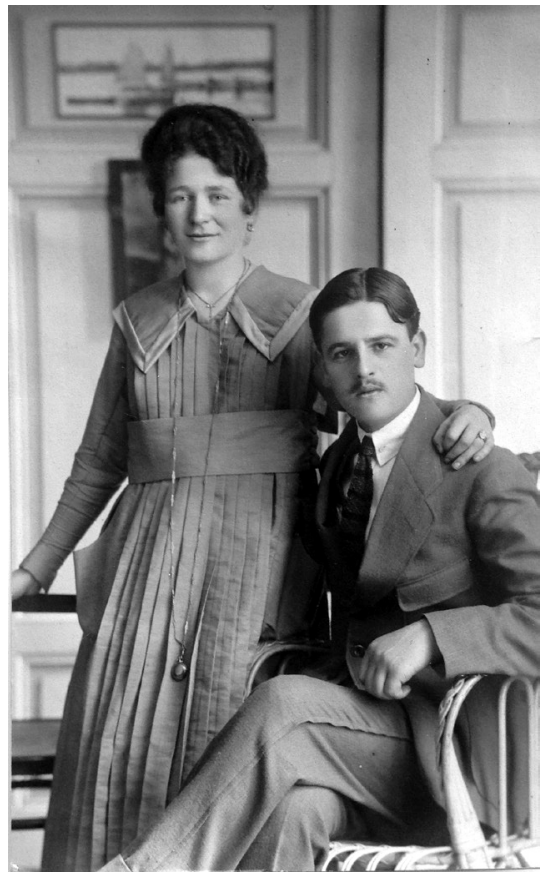

Figure 2: Esther (Elsa) Fouks and Chaim (Heinrich) Gablinger from Poland. Esther was sent to work as a housemaid at her aunt's house in Baden at the age of twelve. Chaim arrived in Zurich as a 15-year-old and became a peddler. 